ФІЗИЧНЕ ВИХОВАННЯ РІЗНИХ ГРУП

НАСЕЛЕННЯ
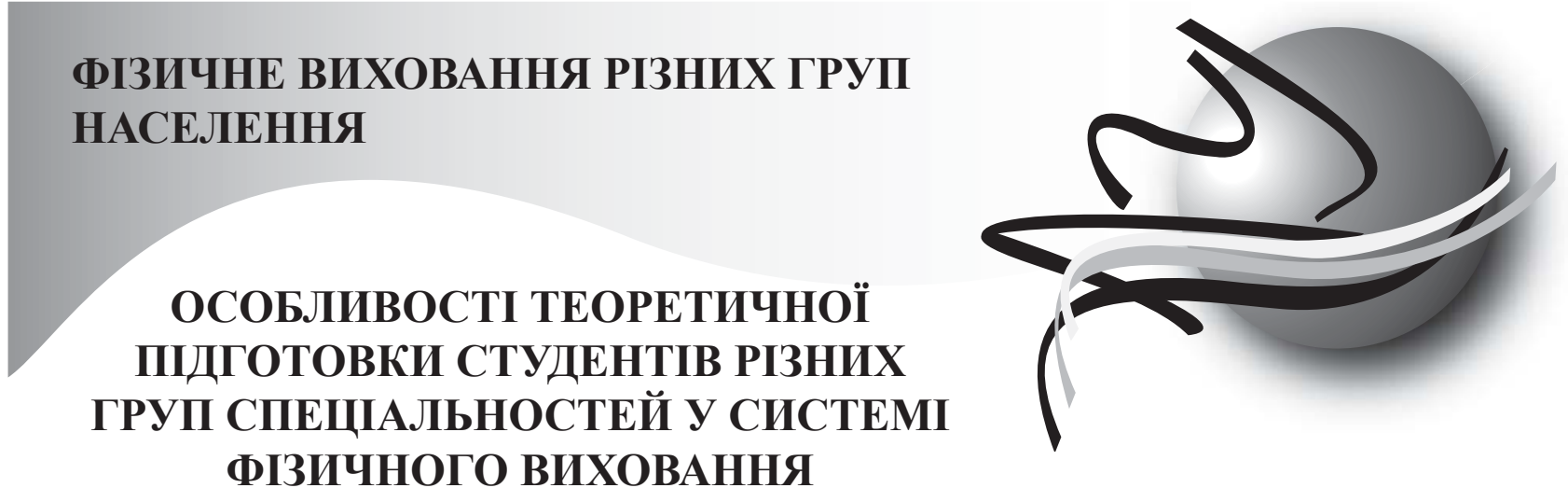

Кочелева Олена ${ }^{1}$, Татарченко Лариса ${ }^{2}$ Рузанов Віктор ${ }^{1}$

${ }^{1}$ Придніпровська державна академія фізичної культури і спорту

²Діпровський національний університет імені Олеся Гончара

\title{
DOI: 10.32540/2071-1476-2019-4-129
}

\section{Annotation}

Introduction and purpose of the study. The article is devoted to finding ways to increase the effectiveness of theoretical training of students of different groups of specialties in the system of physical education. The urgency of this problem is conditioned by the fact that the theoretical material forms the ideological system of scientific and practical knowledge and the attitude of students to physical culture. In order to increase the effectiveness of the theoretical training of students in the system of physical education, it is proposed to select the teaching methods, taking into account the requirements of future professional activities, to the development of mental qualities. Such an approach will allow not only the formation of knowledge and skills in the field of physical culture, necessary for life, but will also contribute to the formation of general professional competences of future specialists. The hypothesis of the study: it was supposed that the choice of methods of theoretical training of students of different groups of specialisms on the basis of taking into account the requirements of professional activity to the development of mental qualities will contribute to increasing its efficiency, better training future professionals to perform their professional duties. The purpose of the research is to substantiate the conditions for improving the theoretical training of students in the system of physical education on the basis of taking into account the requirements of professional activity to the development of mental qualities.

Materials and methods: analysis, generalization and systematization of data of scientific and methodical literature; pedagogical observation, sociological (questionnaires, surveys); method of expert evaluation, methods of mathematical statistics. The research was conducted on the basis of higher education institutions of the city of Dnipro. The study was attended by 60 teachers of the departments of physical education aged 23 to 72 years and the experience of teaching work in ZVO from 1 to 47 years.

Results. The analysis of scientific and methodological literature shows that the approach to the formation of knowledge used in the practice of the educational process of physical education often reduces to the mechanical transmission of the finished information, which does not contribute to the increase of cognitive activity of students, does not allow to fully develop the professional competence of future health professionals So, finding solutions to this problem remains relevant. On the basis of the analysis of literary sources, professionally significant mental qualities of specialists of different groups of specialties are established. According to the results of the questioning of teachers, the methods of theoretical training and the task of forming the general professional competences of students of different groups of specialties are determined. The results of the survey show that $83.3 \%$ of teachers of physical education point out the lack of effectiveness of traditional forms and methods of theoretical training and consider it appropriate to introduce interactive teaching methods to stimulate cognitive activity of students. The proposed conditions for increasing the effectiveness of theoretical training of students on the basis of taking into account the requirements of professional activities were subject to expert evaluation of specialists. Analysis of the results shows that most experts consider them to be more effective compared to those available in higher education institutions $(\mathrm{W}=0.8)$. At the same time, $66.6 \%$ of teachers do not feel ready for practical application of the listed methods in practice. This situation proves the expedi-

(c) Кошелева О., Татарченко Л.,

Рузанов В., 2019 
ency of forming instructors of physical education the necessary knowledge and skills through conducting methodological seminars and trainings in order to familiarize them with the content of modern active teaching methods and prepare them for the practical application of the listed methods in the practice of physical education.

Conclusions. The results of the study indicate the expediency of using modern interactive teaching methods in the system of physical education of students to improve the quality of theoretical training. It is expedient to choose interactive methods taking into account the requirements of the future profession to the development of mental qualities, which will promote the development of professionally meaningful mental qualities and the formation of general professional competences of students of different groups of specialties. For the effective implementation of the listed methods in the practice of the educational process of physical education, it is necessary to prepare scientific and pedagogical methods for their practical use in the system of classes.

Key words: students, theoretical training, system of physical education, mental qualities, interactive methods of teaching.

\section{Анотація}

Вступ і мета дослідження. Стаття присвячена пошуку шляхів підвищення ефективності теоретичної підготовки студентів різних груп спеціальностей у системі фізичного виховання. Актуальність цієї проблеми обумовлюється тим, що теоретичний матеріал формує світоглядну систему науково-практичних знань $\mathrm{i}$ ставлення студентів до фізичної культури. Для підвищення ефективності теоретичної підготовки студентів у системі фізичного виховання пропонується здійснювати вибір методів навчання з урахуванням вимог майбутньої професійної діяльності до розвитку психічних якостей. Такий підхід дозволить не лише формувати знання та навички в сфері фізичної культури, необхідні в життедіяльності, але й буде сприяти формуванню загальних професійних компетентностей майбутніх фахівців. Гіпотеза дослідження: передбачалось, що вибір методів теоретичної підготовки студентів різних груп спеціальностей на основі урахування вимог професійної діяльності до розвитку психічних якостей буде сприяти підвищенню ії ефективності, більш якісній підготовці майбутніх фахівців до виконання професійних обов'язків. Мета дослідження - обгрунтувати умови підвищення ефективності теоретичної підготовки студентів у системі фізичного виховання на основі урахування вимог професійної діяльності до розвитку психічних якостей.

Матеріали та методи: аналіз, узагальнення та систематизація даних науково-методичної літератури; педагогічне спостереження, соціологічні (анкетування, опитування); метод експертної оцінки, методи математичної статистики. Дослідження проводилися на базі закладів вищої освіти міста Дніпра - ДНУ ім. О. Гончара, ПДАБА, ДУАН. У дослідженні взяли участь 60 викладачів кафедр фізичного виховання.

Результати. Аналіз науково-методичної літератури свідчить, що підхід до формування знань, який використовується в практиці навчального процесу з фізичного виховання, часто зводиться до механічної передачі готової інформації, що не сприяє підвищенню пізнавальної активності студентів, не дозволяє повною мірою формувати професійні компетентності майбутніх фахівців в сфері здоров'язбереження, тому пошук шляхів вирішення проблеми залишається актуальним. В ході дослідження автори використовували класифікацію спеціальностей за Л.П. Пилипеєм, яка розроблена на основі аналізу професійних вимог, що пред'являються до людини конкретними спеціальностями. На основі аналізу літературних джерел встановлено професійно значущі психічні якості фахівців різних груп спеціальностей. За результатами анкетування викладачів визначено методи теоретичної підготовки та завдання з формування загальних професійних компетентностей студентів різних груп спеціальностей. Результати анкетування свідчать, що 83,3\% викладачів фізичного виховання відзначають недостатню ефективність традиційних форм і методів теоретичної підготовки та вважають доцільним впровадження інтерактивних методів навчання для стимуляції пізнавальної активності студентів.

Запропоновані умови підвищення ефективності теоретичної підготовки студентів на основі урахування вимог професійної діяльності підлягли експертній оцінці фахівців. Аналіз результатів свідчить, що більшість експертів вважають іх більш ефективними у порівнянні з наявними в $3 \mathrm{BO}(\mathrm{W}=0,8)$. В той же час, $66,6 \%$ викладачів не відчувають готовності до практичного застосування перелічених методів на практиці. Така ситуація свідчить про доцільність формування у викладачів фізичного виховання необхідних знань i навичок шляхом проведення методичних семінарів і тренінгів для ознайомлення їх зі змістом сучасних активних методів навчання та підготовки їх до практичного застосування перелічених методів у практиці фізичного виховання.

Висновки. Результати дослідження свідчать про доцільність використання сучасних інтерактивних методів навчання в системі фізичного виховання студентів для підвищення якості теоретичної підготовки. Вибір інтерактивних методів доцільно здійснювати з урахуванням вимог майбутньої професії до розвит- 
ку психічних якостей, що буде сприяти розвитку професійно значущих психічних якостей і формуванню загальних професійних компетентностей студентів різних груп спеціальностей. Для ефективного впровадження перелічених методів у практику навчального процесу з фізичного виховання, необхідно підготувати науково-педагогічних до їх практичного використання в системі занять.

Ключові слова: студенти, теоретична підготовка, система фізичного виховання, психічні якості, інтерактивні методи навчання.

\section{Аннотация}

Введение и цель исследования. Статья посвящена поиску путей повышения эффективности теоретической подготовки студентов разных групп специальностей в системе физического воспитания. Актуальность данной проблемы обусловлена тем, что теоретический материал формирует мировоззренческую систему научно-практических знаний и отношение студентов к физической культуре. Для повышения эффективности теоретической подготовки студентов в системе физического воспитания предлагается осуществлять выбор методов обучения с учетом требований будущей профессиональной деятельности к развитию психических качеств. Такой подход позволит не только формировать знания и навыки в области физической культуры, необходимые в жизнедеятельности, но и будет способствовать формированию общих профессиональных компетентностей будущих специалистов. Гипотеза исследования: предполагалось, что выбор методов теоретической подготовки для студентов разных специальностей на основе учета требований профессиональной деятельности к развитию психических качеств повысит ее эффективность, будет способствовать более качественной подготовке будущих специалистов к выполнению профессиональных обязанностей. Цель исследования - обосновать условия повышения эффективности теоретической подготовки студентов в системе физического воспитания на основе учета требований профессиональной деятельности.

Материалы и методы: анализ, обобщение и систематизация данных научно-методической литературы; педагогическое наблюдение, социологические (анкетирование, опросы) метод экспертной оценки, методы математической статистики. Исследования проводились на базе высших учебных заведений города Днепра: ДНУ им. О. Гончара, ПДАБА, ДУАН. В исследовании приняли участие 60 преподавателей кафедр физического воспитания.

Результаты. Анализ научно-методической литературы свидетельствует, что подход к формированию знаний, который используется в практике учебного процесса по физическому воспитанию, часто сводится к механической передаче готовой информации, что не способствует повышению познавательной активности студентов, не позволяет в полной мере формировать профессиональные компетентности будущих специалистов в области здоровьесбережения, поэтому поиск путей решения данной проблемы остается актуальным. В ходе исследования авторы использовали классификацию специальностей по Л.П. Пилипея, которая разработана на основе анализа профессиональных требований, предъявляемых к человеку конкретными специальностями. На основе анализа научно-методической литературы установлены профессионально значимые психические качества для студентов разных групп специальностей. Обобщение результатов анкетного опроса преподавателей позволило определить методы теоретической подготовки и задачи по формированию общих профессиональных компетенций студентов разных групп специальностей. Результаты анкетирования свидетельствуют, что $83,3 \%$ преподавателей физического воспитания отмечают недостаточную эффективность традиционных форм и методов теоретической подготовки, считают целесообразным внедрение интерактивных методов обучения для стимуляции познавательной активности студентов. Предложенные условия повышения эффективности теоретической подготовки студентов подверглись экспертной оценке специалистов. Анализ результатов показывает, что большинство экспертов считают их более эффективными, по сравнению с имеющимися в $3 \mathrm{BO}(\mathrm{W}=0,8)$. В то же время, $66,6 \%$ преподавателей не чувствуют готовности к практическому применению предложенных методов на практике. Такая ситуация свидетельствует о целесообразности формирования у преподавателей физического воспитания необходимых знаний и навыков путем проведения методических семинаров и тренингов для освоения ими современных активных методов обучения и подготовки к практическому применению перечисленных методов в практике физического воспитания.

Выводы. Результаты исследования свидетельствуют о целесообразности использования современных интерактивных методов обучения в системе физического воспитания студентов для повышения качества теоретической подготовки. Выбор интерактивных методов обучения целесообразно осуществлять с учетом требований профессиональной деятельности, что будет способствовать не только формированию необходимых знаний, но и развитию профессионально значимых психических качеств, формированию общих профессиональных компетентностей будущих специалистов. Для эффективного внедрения

(C) Кошелева О., Татарченко Л.,

Рузанов В., 2019 
перечисленных методов в практику учебного процесса по физическому воспитанию, необходимо осуществить подготовку преподавательского состава к их практическому использованию.

Ключевые слова: студенты, теоретическая подготовка, система физического воспитания, психические качества, интерактивные методы обучения.

Вступ. В останні роки спостерігається істотне погіршення стану здоров'я і фізичної підготовленості студентської молоді [3,15,16,18]. Більшість дослідників [2,5,6,19] пов'язують це не лише 3 несприятливими соціально-економічними умовами життя і екологією, але і з недостатньою ефективною діючою в ЗВО системою фізичного виховання, що вимагає активного пошуку нових форм і методів ії вдосконалення.

У сучасній науково-методичній літературі представлено широкий спектр досліджень, в яких пропонуються підходи до удосконалення різних складових фізичного виховання в закладах вищої освіти. Зокрема, дослідниками багато уваги приділяється пошуку шляхів підвищення ефективності теоретичної підготовки студентів у системі фізичного виховання. Підвищена увага вчених до вирішення цього питання пояснюється тим, що теоретичні знання формують світоглядну систему науково-практичних знань i ставлення студентів до фізичної культури. Вони необхідні для розуміння соціальних процесів функціонування фізичної культури суспільства і особистості, вміння їх творчо використовувати для професійно-особистісного розвитку, самовдосконалення, організації здорового способу життя при виконанні навчальної, професійної та соціокультурної діяльності. Варто відзначити, що більшість науковців, вважають недостатньою кількість аудиторних годин, які виділяються на вивчення теоретичного розділу програми [1,2,7]. Водночас, збільшення кількості годин відведених на теоретичну підготовку, неминуче призведе до зменшення практичних занять, і як наслідок, - до зниження рухової активності студентів. Існуюче протиріччя підкреслюється низькою залученістю студентів до позанавчальних форм фізичного виховання, що унеможливлює підвищення рівня їх фізкультурної освіченості за рахунок факультативних і консультативних занять. На цьому фоні очевидним постає протиріччя між необхідністю підвищення рівня теоретичної підготовленості студентів і низькою ефективністю навчально-методичної роботи, - як в рамках академічних занять, так i в позанавчальний час. Саме тому в останні роки питанню вдосконалення теоретичної підготовки студентів в системі фізичного виховання приділялось багато уваги. О.А. Томенком [20] розроблена концептуальна модель неспеціальної фізкультурної освіти учнівської та студентської молоді, яка містить мету, завдання, принципи, функції, рівні організації, зміст, форми реалізації, засоби та контроль неспеціальної фізкультурної освіченості.

Окремої уваги заслуговує досвід впровадження в навчальний процес $з$ фізичного виховання інтерактивного навчання для підвищення ефективності теоретичної підготовки студентів. Дослідженню цієї проблеми присвячено праці Москаленко Н.В., Кожедуб Т.Г. [10,11], Сичової Т.В.[17]. Як відмічають фахівці $[5,9,12]$, особливість інтерактивного навчання полягає в тому, що навчальний процес здійснюється за умови постійної, активної взаємодії усіх його учасників. Аналізуючи свої дії та дії партнерів, суб'єкти навчального процесу змінюють свою модель поведінки, більш усвідомлено засвоюють знання та вміння, тому є сенс говорити про інтерактивні методи не тільки як засіб покращення навчання, але й як засіб посилення виховних впливів.

В останні роки в закладах вищої освіти спостерігається скорочення кількості академічних годин на вивчення дисципліни «Фізичне виховання», що підвищує значення самостійних занять фізичними вправами студентів, грамотне планування яких неможливо без володіння необхідним обсягом знань 3 фізичної культури та спорту. 3 метою вирішення цього питання Н.Л. Корж [6] розроблено інноваційні підходи до організації теоретичної підготовки студентів 3 використанням інтерактивних методів для оволодіння знаннями, які необхідні при плануванні самостійних занять фізичними вправами. В.С. Мунтян [12] запропонована дистанційна технологія фізичного виховання студентів, яка передбачає формування знань, необхідних при самостійному програмуванні занять. У руслі сучасних тенденцій модернізації освітнього процесу А.С. Ільницька [4] запропонувала використовувати інтернет-технології для формування знань і стимуляції інтересу студентів до занять фізичною культурою.

Таким чином, у сучасній науково-методичній літературі представлена достатня кількість робіт, присвячених проблемі підвищення ефективності теоретичної підготовки студентів. У той же час, фахівці [5,9] відзначають, що незважаючи на велику кількість наукових досліджень, в практиці навчального процесу з фізичного виховання формування знань часто зводиться до механічної пере- 
дачі готової інформації, а в більшості випадків навіть цей спосіб не використовується, і на заняттях вирішуються лише завдання фізичної підготовки. Тому пошук шляхів вирішення проблеми залишається актуальним.

На наш погляд, для підвищення ефективності теоретичної підготовки студентів у системі фізичного виховання доцільно здійснювати вибір методів навчання 3 урахуванням вимог майбутньої професії до розвитку психічних якостей. Такий підхід дозволить не лише формувати знання та навички в сфері фізичної культури, необхідні в життєдіяльності, але й буде сприяти формуванню професійних компетентностей майбутніх фахівців.

Гіпотеза дослідження полягає в тому, що вибір методів теоретичної підготовки для студентів різних спеціальностей 3 урахуванням вимог професійної діяльності підвищить ㄲï ефективність, буде сприяти більш якісній підготовці майбутніх фахівців до виконання професійних обов'язків.

Вищевикладене визначає мету статті - обгрунтувати умови підвищення ефективності теоретичної підготовки студентів у системі фізичного виховання на основі урахування вимог професійної діяльності.

Методи дослідження: аналіз, узагальнення та систематизація даних науково-методичної літератури; педагогічне спостереження, соціологічні (анкетування, опитування); метод експертної оцінки, методи математичної статистики.

Організація дослідження. Дослідження проводилися на базі закладів вищої освіти міста Дніпра - Дніпровського національного університету імені Олеся Гончара (ДНУ ім. О. Гончара), ДВНЗ «Придніпровська державна академія будівництва та архітектури» (ПДАБА), Дніпровського університету імені Альфреда Нобеля (ДУАН). У дослідженні взяли участь 60 викладачів кафедр фізичного виховання у віці від 23 до 72 років і стажем викладацької роботи в роботи у ЗВО від 1 до 47 років.

Статистичний аналіз. Експериментальні дані оброблялися за допомогою методів математичної статистики (описова статистика).

Результати. В теорії і методиці фізичного виховання розроблено підходи, в яких пропонується об'єднувати спеціальності в групи, з урахуванням вимог майбутньої професії. Використовуючи одну $з$ таких класифікацій, можна об'єднати всі представлені в ЗВО спеціальності в кілька груп і визначати зміст фізичної підготовки не для кожної окремо взятої спеціальності, а для групи спеціальностей, які пред'являють схожі вимоги до дій, якостей і можливостей фахівця.

У нашій роботі ми скористалися класифікацією спеціальностей для побудови системи ППФП, запропонованої Л.П. Пилипеєм [13] в 2009 році. Ця класифікація розроблена на основі аналізу професійних вимог, що пред'являються до людини конкретними спеціальностями. Автор систематизував і згрупував окремі спеціальності в 6 груп: інформаційно-логічна; комунікативна; творчо-образна; технічна; екстремальна; природно-аграрна.

Кожен із закладів вищої світи, на базі яких ми проводили дослідження, здійснює підготовку фахівців за різними групами спеціальностей. В ДНУ ім. О.Гончара здійснюється підготовка фахівців 379 спеціальностей у різних галузях знань, непов'язаних між собою. Розподіл спеціальностей, за якими здійснюється підготовка фахівців у даному ЗВО, відповідно до класифікації, запропонованої Л.П. Пилипеєм, показує, що в ДНУ ім. О. Гончара представлені 5 груп спеціальностей із 6 (інформаційно-логічна; комунікативна; творчо-образна; технічна; природно-аграрна).

ПДАБА $є$ технічним ЗВО, що спеціалізується на підготовці фахівців для сфери будівництва i архітектури за 19 спеціальностями. Спеціальності, за якими здійснюється освітній процес в цьому ЗВО за класифікацією Л.П. Пилипея можуть бути об'єднані в 4 групи (інформаційно-логічна; творчо-образна; технічна; природно-аграрна).

ДУАН - приватний 3ВО, що спеціалізується на підготовці фахівців для сфери управління, бізнесу і права за 13 спеціальностями, які можуть бути об'єднані в 2 групи: (інформаційно-логічна i комунікативна).

Як свідчить аналіз науковометодичної літератури, [13] для кожної з груп професій характерні свої умови праці, психофізіологічні характеристики діяльності, що обумовлює специфічні вимоги до рівня розвитку професійно значущих фізичних i психічних якостей. Вибір засобів і методів фізичного виховання повинен здійснюватися з урахуванням цих вимог.

На теперішній час при складанні стандартів вищої освіти та освітніх (освітньо-професійних чи освітньо-наукових) програм приділяється увага формуванню професійних компетентностей майбутніх фахівців. Саме компетентність як динамічна комбінація знань, умінь і практичних навичок, способів мислення є тією якістю, що визначає здатність особи успішно здійснювати професійну та подальшу навчальну діяльність [14].

У відповідності до положень Національної рамки кваліфікацій розрізняють інтегральні, загальні та спеціальні (фахові, предметні) компетентності.

Інтегральні компетентності представляють собою узагальнений опис кваліфікаційного рівня, який виражає основні компетентнісні характеристики рівня щодо навчання та/або професійної діяльності.

Загальні компетентності - уні-

(c) Кошелева О., Татарченко Л.,

Рузанов В., 2019 
версальні компетентності, що не залежать від предметної сфері, але важливі для успішної подальшої професійної та соціальної діяльності здобувача в різних галузях та для його особистісного розвитку.

Спеціальні (фахові, предметні) компетентності - компетентності, що залежать від предметної області, та $є$ важливими для успішної професійної діяльності за певною спеціальністю.

Впровадження компетентнісного підходу має на меті формування такого змісту освіти, який не буде зводитися до знаннєвоорієнтованого компонента, але й передбачить розвиток здатностей до вирішення життєвих проблем, виконання ключових (тобто, тих, що належать до багатьох соціальних сфер) функцій.

Вирішення завдань фізичного виховання, які спрямовані на формування знань в галузі фізичної культури та навичок їх практичного застосування на практиці в своїй життєдіяльності, на наш погляд, сприятиме формуванню загальних компетентностей майбутніх фахівців, оскільки є дуже важливим для зміцнення та збереження здоров'я, підвищення роботоздатності, забезпечення успішної подальшої професійної та соціальної діяльності та особистісного розвитку.

До переліку загальних компетентностей фахівців усіх спеціальностей доцільно окремим блоком внести компетентності в сфері здоров'язбереження. Особливо важливим вирішення цього питання стає в умовах несприятливої ситуації, яка склалась зі станом здоров'я населення України i, зокрема, студентської молоді. Як свідчать результати чисельних досліджень [3,15,16,18], у великої кількості студентів спостерігається погіршення стану здоров'я та збільшення хронічних захворювань протягом навчання у ЗВО, що пов’язують як 3 напруженою навчальною діяльністю, так і 3 несприятливими умовами побуту. До того ж, специфічні умови майбутньої професійної діяльності також в багатьох випадках пов'язані 3 ризиком виникнення різноманітних захворювань. Все сказане обумовлює необхідність формування у студентів навичок дотримання правил здоров'язбереження. Між тим, аналіз змісту освітніх програм різних спеціальностей свідчить, що їх автори не надають достатньої уваги вирішенню цього питання.

3 усіх навчальних дисциплін, які викладаються у ЗВО нефізкультурного профілю, саме фізичне виховання надає найбільші можливості для формування у майбутніх фахівців компетентностей в сфері здоров'язбереження. Розділ теоретичної підготовки покликано вирішувати питання щодо формування у студентів необхідних знань з основ здорового способу життя та методики використання засобів фізичного виховання для збереження та зміцнення здоров'я. Таким чином, забезпечується комплексний підхід, який у відповідності до сучасних вимог організації освітнього процесу не буде зводитися лише до простого відтворення студентом отриманих знань, але й передбачить розвиток здатностей до вирішення життєвих проблем, пов'язаних 3 необхідністю використання засобів фізичного виховання для досягнення професійних та особистих цілей.

Зміст компетентностей в галузі здоров'язбереження студентів різних груп спеціальностей, на наш погляд, не має суттєвих відмінностей та в достатній мірі відображений в діючий базовій програмі 3 фізичного виховання ЗВО у вигляді критеріїв його ефективності: дотримання основ здорового способу життя; знання 3 основ організації і методики найбільш ефективних видів i форм раціональної рухової діяльності й уміння застосувати їх на практиці у своїй фізичній активності; знання 3 основ методики оздоровлення i фізичного удосконалювання традиційними і нетрадиційними засобами та методами фізичної культури; знання 3 основ професійно-прикладної фізичної підготовки й уміння застосовувати їх на практиці; знання $з$ основ фізичного виховання різних верств населення; сформована навичка до щоденних занять фізичними вправами у різноманітних раціональних формах; поінформованість про всі головні цінності фізичної культури і спорту.

Аналіз літературних джерел $[6,10,11,17,19]$ свідчить, що для більш ефективного вирішення завдань 3 формування професійних компетентностей доцільно використовувати інтерактивні методи навчання в системі фізичного виховання. Інтерактивні методи навчання - це методи, спрямовані на активізацію мислення студентів; методи характеризуються високим ступенем мотивації, емоційного сприйняття навчального процесу і дозволяють активізувати і розвивати пізнавальну і творчу діяльність, підвищувати результативність навчального процесу; формувати й оцінювати компетентності, особливо в частині організації виконання колективної роботи.

Тому нами на основі аналізу науково-методичної літератури [13] було визначено професійно значущі психічні якості фахівців різних груп спеціальностей; викладачам кафедр фізичного виховання було запропоновано добрати методи теоретичної підготовки, які б могли сприяти не лише формуванню знань, але й розвитку визначених якостей. Викладачі могли обирати 3 методів, запропонованих нами, або пропонувати власні варіанти. Також викладачам було запропоновано визначити завдання 3 формування компетентностей, вирішенню яких буде сприяти використання

(c) Кошелева О., Татарченко Л., Рузанов В., 2019 
тих чи інших методів навчання.

Аналіз отриманих результатів дозволив визначити інтерактивні методи теоретичної підготовки студентів різних груп спеціальностей, які в поєднанні $з$ традиційними лекціями, семінарами, консультаціями, роботою з науково-методичною літературою будуть сприяти підвищенню якості теоретичної підготовки, розвитку психічних якостей, необхідних для якісного виконання майбутніх професійних обов'язків, формуванню професійних компетентностей (табл. 1).

Аналіз даних, наведених в таблиці 1, свідчить, що студентам інформаційно-логічної групи спеціальностей в якості провідного методу теоретичної підготовки наші респонденти запропонували методи аналізу конкретних ситуацій для розвитку аналітичного та логічного мислення, уваги, пам'яті, емоційної стійкості, цілеспрямованості, дисциплінованості, ініціативності, ретельності, самостійності, наполегливості, витримки, самовладання; навчання учасників аналізу та алгоритмам вирішення реальних практичних ситуацій, формування навичок відділення важливого від другорядного, які є необхідними для якісного виконання професійних обов'язків фахівцям цієї групи.

Для студентів комунікативної групи професійно значущими психічними якостями $є$ : словесна i емоційна стійкість, витримка, самовладання, логічне мислення, творче мислення, креативність, комунікативність, колективізм, урівноваженість, активність, ініціативність, уміння. висловлювати свої думки, схильність до самоосвіти. 3 метою розвитку цих якостей їм запропонували використовувати дискусійні методи: дебати, дебріфінг, дискусія та ін. Використання дискусійних методів повинно сприяти розвитку комунікативних якостей учасників (вміння доказувати, апелю- вати, дебатувати, висловлювати свою або групову точку зору, формулювати та задавати питання, оцінювати та критикувати), які є провідними для даної групи спеціальностей.

Студентам творчо-образної групи спеціальностей запропонували використовувати ігрові методи (рольові, ситуаційні, ділові, навчальні ігри) для розвитку спостережливості, уваги, короткочасної і довготривалої пам'яті, операційного, творчого, логічного мислення, креативності, комунікативності, активності, ініціативності та формування загальних компетентностей (засвоєння нових ролей та ситуацій, розширення кругозору, формування творчих здібностей, емпатії, рефлексії та ін.).

Для студентів технічної групи провідними психічними якостями $€$ : спостережливість; переключення, розподіл, концентрація, обсяг уваги, емоційна стійкість, оперативне мислення, довготривала i оперативна пам'ять, дисциплінованість, цілеспрямованість, виконавча дисципліна, самостійність, відповідальність, ініціативність, сміливість, рішучість, витримка, самовладання, наполегливість. 3 метою розвитку цих якостей і залучення студентів до активної розумової діяльності, інтеграції зорового та вербального сприйняття інформації, розвитку вміння оперативно аналізувати ситуацію, виділяти невірну або неточну інформацію, їм запропонували різноманітні методи активізації сприйняття (проблемні лекції, лекції-візуалізації, лекції iз заздалегідь запланованими помилками, лекції з використанням техніки зворотнього зв'язку).

Студентам природно-аграрної групи необхідні: емоційна стійкість, здатність до концентрації уваги, творче мислення, аналітичні здібності, відчуття часу, простору, спостережливості, увага, оперативне мислення, цілеспрямованість, дисциплінованість, ініціативність, самостійність, сміливість, наполегливість, витримка. Для розвитку цих якостей та формування професійних компетентностей (дослідницьких вмінь, вмінь спостерігати та робити висновки, застосовувати набуті знання на практиці, визначати сфери та межі застосування результатів дослідження) їм доцільно використовувати пошукові та дослідницькі методи: проект, звіт, програма, доклад та ін.

Запропоновані умови підвищення ефективності теоретичної підготовки студентів в системі фізичного виховання на основі урахування вимог професійної діяльності підлягли експертній оцінці фахівців. Аналіз результатів свідчить, що більшість експертів вважають їх більш ефективними у порівнянні з наявними в $3 \mathrm{BO}(\mathrm{W}=0,8)$.

Але в процесі проведення досліджень ми з'ясували, що значна кількість викладачів відчувають труднощі при визначенні інтерактивних методів навчання для застосування їх в процесі теоретичної підготовки студентів різних груп спеціальностей. Проведене нами анкетування свідчить, що $66,6 \%$ викладачів ніколи не застосовували в своїй професійній діяльності жоден з запропонованих нами методів, не можуть навести власні варіанти активних методів навчання та не відчувають готовності до практичного застосування перелічених методів на практиці. В той же час, 83,3\% викладачів відзначають недостатню ефективність традиційних форм і методів теоретичної підготовки та вважають доцільним впровадження інтерактивних методів навчання для стимуляції пізнавальної активності студентів.

Така ситуація свідчить про доцільність формування у викладачів фізичного виховання необхідних знань і навичок шляхом проведення методичних семінарів та тренінгів 3 метою ознайомлення їх зі змістом сучасних 


\section{Методи теоретичної підготовки студентів різних груп спеціальностей}

\begin{tabular}{|c|c|c|}
\hline Професійно значущі психічні якості & $\begin{array}{c}\text { Методи теоретичної } \\
\text { підготовки }\end{array}$ & $\begin{array}{c}\text { Завдання з формування } \\
\text { професійних компетентностей }\end{array}$ \\
\hline \multicolumn{3}{|c|}{ Інформаційно-логічна група } \\
\hline $\begin{array}{l}\text { Обсяг, розподіл, перемикання, концентрація, } \\
\text { стійкість уваги, оперативне мислення, опера- } \\
\text { тивна і довготривала пам’ять, емоційна стій- } \\
\text { кість, цілеспрямованість, дисциплінованість, } \\
\text { ініціативність, ретельність, самостійність, на- } \\
\text { полегливість, витримка, стійкість, самовладан- } \\
\text { ня }\end{array}$ & $\begin{array}{l}\text { Методи аналізу кон- } \\
\text { кретних ситуацій: } \\
\text { ситуація-проблема, } \\
\text { ситуація оцінка, си- } \\
\text { туація-вправа та ін. }\end{array}$ & $\begin{array}{l}\text { Навчання учасників аналізу та } \\
\text { алгоритмам вирішення реальних } \\
\text { практичних ситуацій, формуван- } \\
\text { ня навичок відділення важливого } \\
\text { від другорядного, демонстрація } \\
\text { характерної для більшості про- } \\
\text { блем великої кількості можливих } \\
\text { рішень }\end{array}$ \\
\hline \multicolumn{3}{|c|}{ Комунікативна група } \\
\hline $\begin{array}{l}\text { Словесна і емоційна стійкість, витримка, } \\
\text { самовладання, логічне мислення, творче } \\
\text { мислення. Креативність, комунікативність, } \\
\text { колективізм, урівноваженість, активність, іні- } \\
\text { ціативність, уміння. висловлювати свої думки } \\
\text { (вербальні якості), схильність до самоосвіти }\end{array}$ & $\begin{array}{l}\text { Дискусійні методи: } \\
\text { дебати, дебріфінг, } \\
\text { дискусія та ін. }\end{array}$ & $\begin{array}{l}\text { Розвиток комунікативних } \\
\text { якостей учасників; вміння до- } \\
\text { казувати, апелювати, дебату- } \\
\text { вати, висловлювати свою або } \\
\text { групову точку зору, форму- } \\
\text { лювати та задавати питання, } \\
\text { оцінювати та критикувати }\end{array}$ \\
\hline \multicolumn{3}{|c|}{ Творчо-образна група } \\
\hline $\begin{array}{l}\text { Спостережливість, високий обсяг, розподі- } \\
\text { лення, переключення, концентрація, стійкість } \\
\text { уваги, розвинена короткочасна і довготривала } \\
\text { пам'ять, операційне мислення: словесна, емо- } \\
\text { ційна стійкість, витримка, самовладання. Ло- } \\
\text { гічне мислення при високому рівні розвитку } \\
\text { творчого мислення, високий рівень аналітич- } \\
\text { ного, синтетичного, дедуктивного мислення, } \\
\text { креативність, комунікативність, психоемоцій- } \\
\text { на урівноваженість, активність, ініціативність }\end{array}$ & $\begin{array}{l}\text { Ігрові методи: рольо- } \\
\text { ві, ситуаційні, ділові, } \\
\text { навчальні ігри }\end{array}$ & $\begin{array}{l}\text { Засвоєння учасниками нового до- } \\
\text { свіду, нових ролей та ситуацій, } \\
\text { розширення кругозору, форму- } \\
\text { вання творчих здібностей, емпа- } \\
\text { тії, рефлексії, розвиток мотивації } \\
\text { до навчальної діяльності }\end{array}$ \\
\hline \multicolumn{3}{|c|}{ Технічна група } \\
\hline $\begin{array}{l}\text { Спостережливість; переключення, розпо- } \\
\text { діл, концентрація, обсяг уваги, емоційна } \\
\text { стійкість, оперативне мислення, довготри- } \\
\text { вала і оперативна пам’ять, дисциплінова- } \\
\text { ність, цілеспрямованість, виконавча дис- } \\
\text { ципліна, самостійність, відповідальність, } \\
\text { ініціативність, сміливість, рішучість, ви- } \\
\text { тримка, самовладання, наполегливість }\end{array}$ & $\begin{array}{l}\text { Методи активізації } \\
\text { сприйняття: про- } \\
\text { блемна лекція, } \\
\text { лекція-візуалізація, } \\
\text { лекція із заздале- } \\
\text { гідь запланованими } \\
\text { помилками, лекція } \\
\text { з використанням } \\
\text { техніки зворот- } \\
\text { нього зв’язку }\end{array}$ & $\begin{array}{l}\text { Залучення студентів до активної } \\
\text { розумової діяльності, інтегра- } \\
\text { ція зорового та вербального } \\
\text { сприйняття інформації, розвиток } \\
\text { вміння оперативно аналізува- } \\
\text { ти ситуацію, виділяти неві- } \\
\text { рну або неточну інформацію }\end{array}$ \\
\hline \multicolumn{3}{|c|}{ Природничо-аграрна група } \\
\hline $\begin{array}{l}\text { Емоційна стійкість, здатність до концентра- } \\
\text { ції уваги, творче мислення, аналітичні здіб- } \\
\text { ності. Оптимальний розвиток відчуття часу, } \\
\text { простору, спостережливості, обсягу розподі- } \\
\text { лу, перемикання уваги, оперативне мислення, } \\
\text { довготривала увага, цілеспрямованість, дис- } \\
\text { циплінованість, ініціативність, самостійність, } \\
\text { сміливість, наполегливість, витримка }\end{array}$ & $\begin{array}{l}\text { Пошукові та дослід- } \\
\text { ницькі методи: про- } \\
\text { ект, звіт, програма, } \\
\text { доповідь та ін. }\end{array}$ & $\begin{array}{l}\text { Формування знань, дослідниць- } \\
\text { ких умінь, умінь спостерігати та } \\
\text { робити висновки, застосовувати } \\
\text { набуті знання на практиці, визна- } \\
\text { чати сфери та межі застосування } \\
\text { результатів дослідження }\end{array}$ \\
\hline
\end{tabular}


активних методів навчання та підготовки їх до практичного застосування перелічених методів у практиці фізичного виховання.

Дискусія. Як зазначають провідні вчені $[2,8,10]$, до чинників впливу на ставлення студентської молоді до занять фізичними вправами варто віднести і чинник знання. Необхідність урахування цього чинника обумовлена його впливом на інші компоненти ставлення: емоційний i поведінковий. Знання про значення занять фізичними вправами для зміцнення та збереження здоров'я, підвищення фізичної i розумової роботоздатності, попередження професійних захворювань стають основою у формуванні мотиваційно-ціннісного ставлення студентів до фізичної культури. Таким чином, саме високий рівень фізкультурної освіченості майбутніх фахівців $\epsilon$ невід'ємною складовою фізичної культури особистості, на формування якої спрямований процес фізичного виховання в закладах вищої освіти. Тому пошуку шляхів підвищення ефективності теоретичної підготовки студентів у системі фізичного виховання за останні роки було присвячено велику кількість наукових досліджень. Вченими пропонувалось упроваджувати інтерактивні методи навчання $[10,11,17,18]$, інтернет-технологіï $[4,12]$, обгрунтовувались технології підготовки студентів до самостійних занять [6,9], ін. Узагальнюючи досвід попередніх досліджень, ми запропонували умови підвищення ефективності теоретичної підготовки студентів на основі урахування вимог професійної діяльності. Запропоновані нами умови передбачають широке використання сучасних активних методів навчання, вибір яких для студентів різних груп спеціальностей обумовлюється їх здатністю впливати на розвиток якостей особистості, які необхідні для досягнення успіху в конкретній професії. Ми вважаємо, що такі умови організації теоретичної підготовки студентів будуть сприяти створенню позитивної емоційної обстановки на заняттях, формуванню у студентів мотиваційно-ціннісного ставлення до фізичної культури і спорту; активної життєвої позиції; готовності реалізовувати отримані знання, вміння і навички у навчальній, соціальній, професійній і громадській діяльності; підвищенню особистісного потенціалу кожного студента; забезпечать співвідношення змісту дисципліни «Фізичне виховання» 3 особливостями професійної діяльності. Все це дозволить не лише більш ефективно вирішувати завдання 3 формування у студентів необхідних знань в галузі фізичної культури і спорту, але й буде сприяти формуванню загальних професійних компетентностей, які не залежать від предметної області, але опосередковано впливають на успішність подальшої професійної та соціальної діяльності.

Узагальнюючи результати проведеного дослідження, ми звертаємо увагу на існуюче протиріччя: 3 одного боку, більшість викладачів (83,3\%), які взяли участь в анкетуванні, вважають доцільним упроваджувати інтерактивні методи навчання в практику навчального процесу 3 фізичного виховання, з іншого - значна частина $(66,6 \%)$ з них не відчувають готовності до їх використання. Таким чином, головну проблему в реалізації запропонованих умов організації теоретичної підготовки студентів різних груп спеціальностей у фізичному вихованні складає недостатня підготовленість викладачів до їх практичного використання в навчальному процесі. Тому закладам вищої освіти необхідно приділити увагу створенню умов для формування інноваційної компетентності викладачів: підвищення їх кваліфікації, постійний обмін педагогічним досвідом; проведення "круглих столів", семінарів, тренінгів, спрямованих на оволодіння інноваційними технологіями в сфері фізичної культури і спорту.

Висновки. 1. Аналіз науковометодичної літератури свідчить, що одним із першочергових завдань, які стоять в наш час перед фахівцями в галузі фізичного виховання, $є$ вдосконалення системи теоретичної підготовки студентів закладів вищої освіти. Теоретичний матеріал формує світоглядну систему науково-практичних знань і ставлення студентів до фізичної культури.

2. Для підвищення ефективності теоретичної підготовки студентів у системі фізичного виховання доцільно здійснювати вибір методів навчання 3 урахуванням вимог майбутньої професії, що буде сприяти розвитку професійно значущих психічних якостей i формуванню загальних професійних компетентностей майбутніх фахівців.

3. Анкетування викладачів свідчить, що 83,3\% 3 них відзначають недостатню ефективність традиційних форм і методів теоретичної підготовки та вважають доцільним впровадження інтерактивних методів навчання для стимуляції пізнавальної активності студентів. При цьому 66,6\% викладачів ніколи не застосовували в своїй професійній діяльності інтерактивні методи навчання та не відчувають готовності до їх практичного застосування на практиці. Тому для ефективного впровадження інтерактивних методів у навчальний процес 3 фізичного виховання необхідно підготувати науково-педагогічних працівників до їх практичного використання в системі занять.

Перспективи подальших досліджень полягають у впровадженні в практику роботи закладів вищої освіти та експериментальній перевірці ефективності запропонованих умов підвищення ефективності теоретичної підготовки в системі фізичного 
виховання студентів різних груп спеціальностей.

Фінансування. Наукова робота не має спеціального фінансування та виконана у відповідності до тематичного плану наукових досліджень Придніпровської державної академії фізичної куль- тури і спорту на 2016-2020 pр. у межах теми «Науково-теоретичні засади вдосконалення процесу фізичного виховання різних груп населення» (номер державної реєстрації 0116U003010).

Вдячності. Висловлюємо вдячність керівництву та науко- во-педагогічним працівникам кафедр фізичного виховання ДНУ iм. О. Гончара, ПДАБА, ДУАН за можливість проведення досліджень.

Конфлікт інтересів. Автори заявляють про відсутність конфлікту інтересів.

\section{Література}

1. Березка C.M. Теоретичні та методичні знання студентів 3 навчальної дисципліни “фізичне виховання”. Педагогіка, психологія та медико-біологічні проблеми фізичного виховання і спорту. 2011. № 3. С.12-14.

2. Вовк Л.В. Теоретические и методологические основы культуры здорового образа жизни студенческой молодежи. Педагогіка, психологія та медико-біологічні проблеми фізичного виховання і спорту: наукова монографія за ред.. проф.. Єрмакова С.С. - Харків: ХДАДМ (ХХПІ), 2007. №12. С. 38-41.

3. Грибан Г.П. Аналіз рухової активності студентів спеціального навчального відділення. Педагогіка, психологія та медико-біологічні проблеми фізичного виховання і спорту : зб. наук. праць. Харків, 2012. № 2. С. 25-28.

4. Ильницкая А.С. Образовательный компонент интернет-технологий как стимулирующий фактор к занятиям физической культурой. Вісник Чернігівського державного педагогічного університету ім. Т.Г. Шевченка / Міжнародна наукова конференція, Чернігів, 2013. Т. 3. С. 33-38.

5. Карпюк I. Формування знань студенів на заняттях фізичним вихованням. Спортивний вісник Придніпров`я. 2004. № 7. С. 115-117.

6. Корж Н. Ефективність технології формування ціннісного ставлення студентів до фізичної культури в процесі самостійних занять. Спортивний вісник Придніпров’я. 2017. № 3. С. 59-64.

7. Кошелева Е.А. Сравнительный анализ эффективности различных подходов к организации теоретической подготовки студентов в системе физического воспитания. Спортивний вісник Придніпров'я. 2017. № 1 С.165-170.

8. Круцевич Т., Нестеренко О. Ставлення студенток до предмету «Фізичне виховання» у вищих навчальних закладах. Спортивний вісник Придніпров я. 2004. № 7. С. 57-59.

9. Матукова Г.І. Формування фізичної культури студентів вищих навчальних закладів у поза аудиторний час: автореф. дис. на здобуття наук. ступеня канд. пед. наук : спец. 13.00.04 «Теорія

\section{Referenses}

1. Berezka S.M. (2011) Teorety`chni ta metody`chni znannya studentiv z navchal'noyi dy`scy`pliny` “fizy`chne vy`xovannya". Pedagogika, psy'xologiya ta medy'ko-biologichni problemy' fizy`chnogo vy`xovannya i sportu. № 3. pp.12-14.

2. Vovk L.V. (2007) Teorety`chesky`e y` metodology`chesky`e osnovy kul'tury zdorovogo obraza zhy`zny`studencheskoj molodezhy`. Pedagogika, psy`xologiya ta medy`ko - biologichni problemy` fizy'chnogo vy`xovannya i sportu: naukova monografiya za red.. prof.. Yermakova S.S. Xarkiv: XDADM (XXPI), - №12. - pp. 38-41.

3. Gry`ban G.P. (2012) Analiz ruxovoyi akty`vnosti studentiv special’nogo navchal’nogo viddilennya. Pedagogika, psy`xologiya ta medy`ko-biologichni problemy` fizy'chnogo vy'xovannya i sportu : zb. nauk. pracz`. - Xarkiv, № 2. - pp. 25-28.

4. Y`l’ny`czkayaA.S. (2013) Obrazovatel’nyj komponenty`nternet-texnology`j kak sty`muly`ruyushhy`j faktor $\mathrm{k}$ zanyaty'yam fy'zy`cheskoj kul'turoj. Visny`k Chernigivs`kogo derzhavnogo pedagogichnogo universy`tetu im. T. G. Shevchenka / Mizhnarodna naukova konferenciya, Chernigiv, T. 3. - pp. 33-38.

5. Karpyuk I. (2004) Formuvannya znan` studeniv na zanyattyax fizy`chny`m vy`xovannyam. Sporty`vny`j visny`k Pry`dniprov`ya. №7. - pp. 115-117.

6. Korzh N. (2017) Efekty 'vnist' texnologiyi formuvannya cinnisnogo stavlennya studentiv do fizy chnoyi kul`tury` $v$ procesi samostijny`x zanyat’. Sporty`vny`j visny`k Pry`dniprov'ya. № 3. pp. 59-64.

7. Kosheleva E.A. (2017) Sravnitelnyy analiz effektivnosti razlichnykh podkhodov $\mathrm{k}$ organizatsii teoreticheskoy podgotovki studentov $\mathrm{v}$ sisteme fizicheskogo vospitaniya. Sportivniy visnik Pridniprov'ya. № 1 pp.165-170.

8. Krutsevich T. . Nesterenko O. (2004) Stavlennya studentok do predmetu «Fizichne vikhovannya» $\mathrm{u}$ vishchikh navchalnikh zakladakh. Sportivniy visnik Pridniprov`ya. №7. - pp. 57-59.

9. Matukova G.I. (2005) Formuvannya fizichnoï 
і методика професійної освіти». - Кіровоградський держ. пед. ун-т імені Володимира Винниченка. Кіровоград, 2005. 29 с.

10. Москаленко Н.В. Кожедуб Т.Г. Інноваційні підходи до теоретичної підготовки у фізичному вихованні : навч. посіб. Дніпропетровськ : Інновація, 2015. 108 с.

11. МоскаленкоН.В.,Сидорчук Т.В.Инновационные технологии теоретической подготовки в системе физического воспитания.Олимпийский спорт и спорт для всех :материалы XIX Международного научного конгресса, 6-9 октября 2015 г., г. Ереван. С. 364-367.

12. Мунтян В.С. Дистанционное обучение в физическом воспитании. Strategicznepytania światowejnauki. 2014. Przemyśl :Naukaistudia. S. 5-8. (Volume 14. Pedagogicznenauki).

13. Пилипей Л.П. Професійно-прикладна фізична підготовка студентів.: монографія. Суми: ДВНЗ «УАБС НБУ», 2009. 312 с.

14. Про вищу освіту: Закон України від 01.07.2014 № 1556. VII, редакція від 01.01.2019. http:// zakon2.rada.gov.ua/laws/show/1556-18

15. Раевский Р.Т., Канишевский С.М. Здоровье, здоровый и оздоровительный образ жизни студентов. О.: Наука и техника, 2008. 279 с.

16. Самошкіна А. Стан фізичного здоров'я студентів вищих навчальних закладів. Молода спортивна наука України. 2012. Т.2. С. 184-187.

17. Сичова Т. Засоби підвищення рівня теоретичної підготовленості студенток в процесі фізичного виховання. Молода спортивна наука України. 2012. C. $123-126$.

18. Сичова Т. Рухова активність та здоров'я студенток. Спортивний вісник Придніпров'я. 2011. № 2. C. 58-61.

19. Сичова Т.В. Інноваційні технології зміцнення здоров я студенток в процесі фізичного виховання : дис. ... канд. наук з фіз. вих. та спорту : 24.00.02 ; Дніпропетр. держ. ін.-т фіз. культури і спорту. Д., 2012. 290 с.

20. Томенко О.А. Теоретико-методологічні основи неспеціальної фізкультурної освіти учнівської молоді : автореф. дис. на здобуття наук. ступеня докт. наук з фіз. вихов. і спорту : спец. 24.00.02 «Фізична культура, фізичне виховання різних груп населення». К., 2012. 37 с.

21. Behzadnia B., Adachi P., Deca E., Mohammadzadeh H. Associations between students' perceptions of physical education teachers' interpersonal styles and students' wellness, knowledge, performance, and intentions to persist at physical activity: A self-determination theory approach. Psychology of Sport and Exarcise. 2018. Vol. 39. P. 10-19.

22. Brick J. Interactive physical education games. Livestrong. May, 2011. kulturi studentiv vishchikh navchalnikh zakladiv $\mathrm{u}$ poza auditorniy chas: avtoref. dis. na zdobuttya nauk. stupenya kand. ped. nauk : spets. 13.00.04 «Teoriya i metodika profesiynoï osviti». Kirovogradskiy derzh. ped. un-t imeni Volodimira Vinnichenka. - Kirovograd, 29 p.

10. Moskalenko N.V. Kozhedub T.G. (2015) Innovatsiyni pidkhodi do teoretichnoï pidgotovki u fizichnomu vikhovanni : navch. posib.Dnipropetrovsk : Innovatsiya.108 p.

11. Moskalenko N.V.. Sidorchuk T.V. Innovatsionnyye tekhnologii teoreticheskoy podgotovki v sisteme fizicheskogo vospitaniya.Olimpiyskiy sport i sport dlya vsekh :materialy KhIKh Mezhdunarodnogo nauchnogo kongressa. 6-9 oktyabrya 2015g.. g. Erevan. pp. 364-367

12. Muntyan V.S. (2014) Distantsionnoye obucheniye v fizicheskom vospitanii. Strategicznepytania światowejnauki - Przemyśl :Naukaistudia. - pp. 5-8. - (Volume 14. Pedagogicznenauki).

13. Pilipey L.P. (2009) Profesiyno-prikladna fizichna pidgotovka studentiv. :monografiya.- Sumi: DVNZ «UABS NBU». - 312p.

14. Pro vishchu osvitu: Zakon Ukraïni vid 01.07.2014 № 1556 - VII. redaktsiya vid 01.01.2019. http:// zakon2.rada.gov.ua/laws/show/1556-18

15. Rayevskiy R.T.. Kanishevskiy S.M. (2008) Zdorovye. zdorovyy i ozdorovitelnyy obraz zhizni studentov. O.: Nauka i tekhnika, 279 p.

16. Samoshkina A. (2012) Stan fizichnogo zdorov'ya studentiv vishchikh navchalnikh zakladiv. Moloda sportivna nauka Ukraïni T.2. pp. 184-187.

17. Sichova T. (2012) Zasobi pidvishchennya rivnya teoretichnoï pidgotovlenosti studentok v protsesi fizichnogo vikhovannya. Moloda sportivna nauka Ukraïni. pp.123-126.

18. Sichova T.(2011) Rukhova aktivnist ta zdorov'ya studentok. Sportivniy visnik Pridniprov’ya. - №2. - pp. 58-61.

19. Sichova T.V. (2012) Innovatsiyni tekhnologii zmitsnennya zdorov`ya studentok $\mathrm{v}$ protsesi fizichnogo vikhovannya : dis. ... kand. nauk $\mathrm{z}$ fiz. vikh. ta sportu : 24.00 .02 ; Dnipropetr. derzh. in.-t fiz. kulturi i sportu.- D. $290 \mathrm{~s}$.

20. Tomenko O.A. (2012) Teoretiko-metodologichni osnovi nespetsialnoï fizkulturnoï osviti uchnivskoï molodi : avtoref. dis. na zdobuttya nauk. stupenya dokt. nauk z fiz. vikhov. i sportu : spets. 24.00.02 «Fizichna kultura. fizichne vikhovannya riznikh grup naselennya». - K..37 p.

21. Behzadnia B., Adachi P., Deca E., Mohammadzadeh H. (2018) Associations between students' perceptions of physical education teachers' interpersonal styles and students' wellness, knowledge, performance, and intentions to persist at physical activity: A self-determination theory approach.

(c) Кошелева О., Татарченко Л.,

Рузанов В., 2019 
23. Brophy Jere E. Motivating students to learn. Michigan State University, 1998. 278 p.

24. Ellis K., Lieberman L., LeRoux D. Using differentiated instruction in physical education. Originally appeared in Palaestra. 2009. Number 4. Volume 24.

25. Fejgin N. Participation in high school competitive sports: A subversion of school mission or contribution to academic goals? Sociology of Sport Journal. 1994. № 11. P. 211-230.

26. Lund J., Tannehill D. Standarts-based physical education curriculum development. Boston: Jones and Bartlett's Publishers, 2005. 338 p.

27. Stasiuk R.M. Pedagogical conditions of motivational-value relation of students to physical culture. Інноваційні технології в системі підвищення кваліфікації фахівців фізичного виховання і спорту: тези доповідей I Міжнародної науково-методичної конференції, м. Суми, 1718 квітня 2014 р. Суми : Сумський державний університет, 2014. С. 61-62.
Psychology of Sport and Exarcise. Vol. 39. P. $10-$ 19.

22. Brick J. Interactive physical education games. Livestrong. May, 2011.

23. Brophy Jere E. Motivating students to learn. Michigan State University, 1998. 278 p.

24. Ellis K., Lieberman L., LeRoux D. Using differentiated instruction in physical education. Originally appeared in Palaestra. 2009. Number 4. Volume 24.

25. Fejgin N. Participation in high school competitive sports: A subversion of school mission or contribution to academic goals? Sociology of Sport Journal. 1994. №11. P. 211-230.

26. Lund J., Tannehill D. Standarts-based physical education curriculum development. Boston: Jones and Bartlett's Publishers, 2005. 338 p.

27. Stasiuk R.M. Pedagogical conditions of motivational-value relation of students to physical culture. Innovatsiyni tekhnologiï $\mathrm{v}$ sistemi pidvishchennya kvalifikatsiï fakhivtsiv fizichnogo vikhovannya i sportu: tezi dopovidey I Mizhnarodnoï naukovometodichnoï konferentsiï. m. Sumi. 17-18 kvitnya 2014 r. Sumi : Sumskiy derzhavniy universitet. 2014. pp. 61-62.

\section{Кошелева Олена}

Придніпровська державна академія фізичної культури і спорту м. Дніпро, вул. Набережна Перемоги, 10, 49094, Україна

\section{Татарченко Лариса}

Придніпровська державна академія фізичної культури і спорту м. Дніпро, вул. Набережна Перемоги, 10, 49094, Україна

\section{Рузанов Віктор}

Придніпровська державна академія фізичної культури і спорту

м. Дніпро, вул. Набережна Перемоги,10, 49094, Україна 